М. М. Мурадов (к.т.н., доц.), Н. А. Муршудлу (докторант),

И. Г. Гусейнова (докторант), А. А. Агаев (д.х.н., проф.)

\title{
КАТАЛИТИЧЕСКОЕ ПРЕВРАЩЕНИЕ 2,5-ДИМЕТИЛФЕНОЛА
}

\author{
Сумгайытский государственный университет, кафедра нефтехимии и химической инженерии \\ AZ 5008, г. Республика Азербайджан, Сумгайыт, 43-квл; тел. (+994)503324678, e-mail: mailoglu@mail.ru
}

\section{M. Muradov, N. A. Murshudlu, I. Kh. Khuseynova, A. A. Agayev \\ CATALYTIC TRANSFORMATION OF 2,5-DIMETHYLPHENOL}

\author{
Sumgait State University \\ 43rd quarter, AZ 5008, Sumgait, Republic of Azerbaijan; ph. (+994) 503324678, e-mail: mailoglu@mail.ru
}

\begin{abstract}
Проведено сравнение активности и селективности палладиевых катализаторов, содержащих декатионированные формы цеолита семейства пентасила-ЦВМ и морденита в реакции изомеризации-2,5-диметилфенола. Показано, что на РdНЦВМ протекала селективная изомеризация ксиленола с образованием преимущественно 3,5-изомера, в то время, как в присутствии $\mathrm{PdH}$ морденита имело место и заметное диспропорционирование 2,5-диметилфенола с образованием смеси крезолов и триметилфенолов.
\end{abstract}

Ключевые слова: диметилбензол; 2,5-диметилфенол; 3,5-диметилфенол; ксиленол; Н-морденит; триметилфенол; пентасил-ЦВМ.

В производстве новолачных и резольных олигомеров широко используют гомологи фенола-крезолы и ксиленолы, представляющие собой техническую смесь изомеров. Ценность этой исходной смеси для получения олигомеров определяется наличием в ней 3,5-диметилфенола и 3-метилфенола, поскольку только эти изомеры являются трифункциональными ${ }^{\mathbf{1}}$. Кроме того, эти изомеры легче взаимодействуют с электрофильными реагентами, чем фенол. Известно, что скорость реакции поликонденсации 3-метилфенола с формальдегидом превосходит скорость аналогичной реакции фенола в 2.9 раза, а в случае 3,5-диметилфенола - в 7.8 раза. Поэтому для увеличения эффективности процесса и улучшения физико-механических свойств полученных олигомеров обычно до 40\% исходного фенола заменяют ксиленолом ${ }^{2}$.

Получение 3,5-диметилфенола основывается на коксохимическом сырье и изофороно-

\begin{abstract}
The activity and selectivity of palladium catalysts containing decationized forms of the zeolite of the pentasil-SVM family and mordenite in the isomerization-2,5-dimethylphenol reaction were compared. It was shown that selective isomerization of xylenol proceeded with the formation of predominantly 3,5-isomer at PdNSVM, whereas in the presence of $\mathrm{PdH}$ mordenite, there was also a noticeable disproportionation of 2,5-dimethylphenol with the formation of a mixture of cresols and trimethylphenols.
\end{abstract}

Key words: dimethylbenzene; 2,5-dimethylphenol; 3,5-dimethylphenol; H-mordenite; pentasil-CMB; trimethylphenol; xylenol.

Дата поступления 18.03.18 


\section{Материалы и методы исследования}

2,5-диметилфенол (чистота $99.0 \%$, температура кипения $-211.5^{\circ} \mathrm{C}$, температура плавления $74.5{ }^{\circ} \mathrm{C}$, плотность 1.169 г/ $\mathrm{cm}^{3}$ ) получали методом алкилирования 3-метилфенола метанолом в присутствии $\mathrm{PdCaY} 5$. Методика приготовления катализаторов приведена в ${ }^{\mathbf{6}}$.

Палладий в количестве $1.0 \%$ мас. вводили в гранулы смеси цеолита с $\gamma$-оксидом алюминия. Содержание цеолита в образцах катализаторов было одинаковым. Испытание активности катализаторов и опыты проводили в проточном реакторе. Загрузка катализатора $10 \mathrm{~cm}^{3}$. Перед подачей сырья катализаторы прокаливали при температуре $450{ }^{\circ} \mathrm{C}$ в токе сухого воздуха (1 ч, 1000 ч$\left.^{-1}\right)$, затем выдерживали 1 ч в токе водорода $\left(1000\right.$ ч $\left.^{-1}\right)$ при температуре $400{ }^{\circ} \mathrm{C}$ и давлении 0.8 МПа.

Продукты конденсировали в холодильнике-сепараторе при температуре $0-8{ }^{\circ} \mathrm{C}$ и давлении 0.8 МПа и анализировали методом ГЖХ на хроматографе Хром 5 М (Чехия). Трудноразделяемые диметилфенолы анализировали на капиллярной колонне с диментилфталатом по методике, приведенной в ${ }^{7}$. ПМР спектры полученных продуктов снимали на спектрометре Bruker AV-300 (Германия).

С целью изучения протекания не только основных, но и побочных реакций исследования проводили при больших глубинах превращений ксиленола в условиях, используемых в промышленности.

\section{Результаты и их обсуждение}

Конверсия 2.5-диметилфенола на палладиевом катализаторе, содержащем цеолит НЦВМ (PdНЦВМ), была большей, чем на палладиевом катализаторе, содержащем $\mathrm{H}$ морденит (PdHM), а состав продуктов резко различался (табл. 1,2).

На катализаторе РdНЦВМ 2,5-диметилфенол с наиболее высокой селективностью (80.9\%) превращался в другие ксиленолы, с и меньшей скоростью протекала реакция диспропорционирования ксиленола в крезол и триметилфенол. Кроме того, на пентасиле заметно протекала реакция дегидратации ксиленола с образованием простых ароматических эфиров и их последующий гидрокрекинг. Полученные арены состояли в основном из толуола и ксилола. Увеличение удельной нагрузки от 0.5 до 1.5 ч $^{-1}$ снижало селективность образования аренов, при этом наблюдался рост концентрации диметилбензолов в смеси ароматических углеводородов от 65.0 до $90.0 \%$ мас. Аналогичные изменения в составе аренов обнаружены и при каталитическом превращении 2,5-диметилфенола на PdHM, хотя следует отметить, что на морденитном катализаторе их доля была незначительна. В отличие от пентасила, на катализаторе PdHM заметно протекала реакция диспропорционирования 2,5-диметилфенола. Полученная крезольная фракция состояла преимущественно из $\mathcal{M}^{-}$и $\mathrm{O}^{-}$изомеров, а в составе триметилфенолов наблюдалась

Таблица 1

\begin{tabular}{|c|c|c|c|c|c|c|c|}
\hline \multirow{2}{*}{$\begin{array}{c}\text { Удельная } \\
\text { нагрузка, } \\
\text { 4-1 }^{-1}\end{array}$} & \multirow{2}{*}{$\begin{array}{l}\text { Конвер сия, } \\
\text { \% мас. }\end{array}$} & \multicolumn{6}{|c|}{ Селективность превращения в продукты, \% } \\
\hline & & Арены & Крезолы & Другие ДМФ & 3,5-ДМФ & 3,4-ДМФ & TMФ \\
\hline \multicolumn{8}{|c|}{ катализатор Pd-НЦВМ } \\
\hline 0.5 & 71.0 & 12.0 & 2.0 & 8.0 & 51.5 & 21.0 & 3.0 \\
\hline 1.0 & 57.0 & 9.5 & 3.0 & 6.5 & 55.8 & 19.0 & 2.2 \\
\hline \multicolumn{8}{|c|}{ катализатор PdHM } \\
\hline 0.5 & 60.0 & 3.5 & 14.5 & 10.0 & 43.0 & 14.5 & 13.5 \\
\hline 1.0 & 49.5 & 2.0 & 11.0 & 9.5 & 48.5 & 13.0 & 12.0 \\
\hline
\end{tabular}

* ДМФ-диметилфенол; ** ТМФ-триметилфенол.

Таблица 2

Изомерный состав полученных ксиленолов при превращении

2,5-диметилфенола на катализаторах РdНЦВМ и РdHМ

( $\left.\mathrm{T}=400^{\circ} \mathrm{C}, \mathrm{P}=0.8 \mathrm{M \Pi а}, \mathrm{M}_{\mathrm{H}_{2}}: \mathrm{M}_{\text {ксиленол }}=5: 1\right)$

\begin{tabular}{|c|c|c|c|c|c|}
\hline \multirow{2}{*}{$\begin{array}{c}\text { Удельная } \\
\text { нагрузка ч }^{-1}\end{array}$} & \multicolumn{5}{|c|}{ Изомерный состав ксиленолов, \% мас. } \\
\hline & 3,5-ДМФ & 3,4-ДМФ & 2,3-ДМФ & 2,4-ДМФ & 2,5-ДМФ \\
\hline \multicolumn{6}{|c|}{ Катализатор РdНЦВМ } \\
\hline 0.5 & 42.4 & 17.4 & 3.0 & 3.5 & 33.7 \\
\hline 1.0 & 35.6 & 12.1 & 2.0 & 2.1 & 48.2 \\
\hline \multicolumn{6}{|c|}{ Катализатор PdHM } \\
\hline 0.5 & 32.0 & 10.8 & 3.4 & 4.0 & 49.8 \\
\hline 1.0 & 28.0 & 7.5 & 2.0 & 3.5 & 59.0 \\
\hline
\end{tabular}


повышенная концентрация 2,3,6-триметилфенола. Кроме этого изомера, в смеси мезитолов присутствовали 2,4,6-, 2,4,5-триметилфенолы.

Изомеризация 2.5-диметилфенола на PdHM протекала с меньшей селективностью по 3,5-, 3,4-, 2,3- и 2,4-ксиленолам (71.0\%), чем на катализаторе РdНЦВМ. Тип цеолита оказывал существенное влияние и на состав полученных ксиленолов. На катализаторе РdНЦВМ содержание 3,5-диметилфенола в смеси ксиленолов достигало $42.4 \%$, в то время как на PdHM концентрация 3,5-диметилфенола не превышала $32.0 \%$. Необходимо отметить, что на обоих катализаторах 2,5-диметилфенол изомеризовался преимущественно в 3,5-изомер.

В результате проведенных исследований установлено, что бифункциональные катализаторы РdНЦВМ и РdНM обеспечивают раз-

\section{Литература}

1. Кошель Г.Н., Нестерова Т.Н., Румянцева Ю.Б., Курганова Е.А., Иванова А.А. Цимолы. 4. Получение крезолов и их применение $/ / \mathrm{Be}$ стник МИТХТ им. М. В. Ломоносова.- 2012.T.7, №6.- C.56-60.

2. Fiege H. Cresols and xylenols. Int. Ulmann's Encyclopedia of Industrial Chemistry.- VCH Verlagsgecellchaft, 1991.- №8.- Pp.25-28.

3. Харлампович Г.Д., Чуркин Ю.В. Фенолы.М.: Химия, 1974.-376 с

4. Agliullin M.R., Danilova I.G., Faizullin A.V., Amarantov S.V., Bubennov S.V., Prosochkina T.R., Grigor'Eva N.G., Paukshtis E.A., Kutepov B.I. Sol-Gel Synthesis of Mesoporous Aluminosilicates with a Narrow Pore Size Distribution and Catalytic Activity Thereof in the Oligomerization of Dec-1-ene. // Microporous and Mesoporous Materials. - 2016.V.230.- Pp.118-127.

5. Мурадов М.М., Муршудлу Н.А., Агаев А.А. Получение диметилфенолов алкилированием крезолов метанолом // Баш.хим.ж.- 2018.Т.25, №2.- С.31-34.

6. Агаев А.А., Тагиев Д.Б. Алкилирование фенола метиловым спиртом на высококремнеземных цеолитах // ЖПХ. - 1986. - Т.59, №12.С.2734-2735.

7. Muradov M.M., Shirinova X.N., Huseynova I.Q., Agayev A.A. Alkylation of 2-methylphenol and 2.6-dimethylphenol by methanol in presence of ferritecatalyst / European Journal of Analytical and Applied Chemistry.- 2016.№2.- Pp.34-37. ную глубину превращения 2,5-диметилфенола и селективность изомеризации ксиленола на катализаторе PdНЦВМ больше, чем на катализаторе РdHM.

В найденных условиях реакции на катализаторе PdHM, в отличие от РdНЦВМ, заметно усиливается скорость диспропорционирования 2,5-ксиленола с образованием смеси крезолов и триметилфенолов.

Таким образом, каталитическим превращением 2,5-диметилфенола в присутствии цеолитного катализатора РdНЦВМ и в среде водорода удается синтезировать смесь диметилфенолов, содержащую преимущественно 3,5ксиленол, которая полностью удовлетворяет требованиям, предъявляемым к сырью для производства эффективных ксиленолоформальдегидных олигомеров.

\section{References}

1. Koshel' G.N., Nesterova T.N., Rumyantseva Yu.B., Kurganova E.A., Ivanova A.A. Tsimoly. 4. Polucheniye krezolov $i$ ikh primeneniye [Cymols. 4. Preparation of cresols and their application]. Vestnik MITKHT im. M. V. Lomonosova [Bulletin of the Moscow State Lomonosov Moscow State Institute of Technology], 2012, vol.7, no.6, pp.56-60.

2. Fiege H. [Cresols and xylenols. Int. Ulmann's Encyclopedia of Industrial Chemistry]. VCH Verlagsgecellchaft, 1991, no.8, pp.25-28.

3. Kharlampovich G.D., Churkin Yu.V. Fenoly [Phenols]. Moscow, Khimiya Publ., 1974, 376 p.

4. Agliullin M.R., Danilova I.G., Faizullin A.V., Amarantov S.V., Bubennov S.V., Prosochkina T.R., Grigor'eva N.G., Paukshtis E.A., Kutepov B.I. [Sol-Gel Synthesis of Mesoporous Aluminosilicates with a Narrow Pore Size Distribution and Catalytic Activity Thereof in the Oligomerization of Dec-1-ene]. Microporous and Mesoporous Materials, 2016, vol.230, pp.118-127.

5. Muradov M.M., Murshudlu N.A., Agayev A.A. Production of Dimethylphenols by Alkylation of Cresols With Methanol [Polucheniye dimetilfenolov alkilirovaniyem krezolov metanolom]. Bashkirskii khimicheskii zhurnal [Bashkir Chemical Journal], 2018, vol.25, no.2, pp.31-34.

6. Agayev A.A., Tagiyev D.B. Alkilirovaniye fenola metilovym spirtom na vysokokremnezemnykh tseolitakh [The alkylation of phenol with methyl alcohol under highsilicate zeolites]. Zhurnal prikladnoy khimii [Journal of Applied Chemistry], 1986, vol.59, no.12, pp.2734-2735.

7. Muradov M.M., Shirinova X.N., Huseynova I.Q., Agayev A.A. [Alkylation of- 2 methylphenol and 2.6-dimethylphenol by methanol in presence of ferritecatalyst]. European Journal of Analytical and Applied Chemistry, 2016, no.2, pp.34-37. 